\title{
Isolation of human testicular cells and co-culture with embryonic stem cells
}

\author{
Meenakshi Gaur ${ }^{1,+}$, Cyril Ramathal ${ }^{2,+}$, Renee A Reijo Pera ${ }^{2,3,+}$, Paul J Turek $^{1,4}$ and \\ Constance M John ${ }^{1}$ \\ ${ }^{1}$ MandalMed, Inc., San Francisco, California, USA, ${ }^{2}$ Institute for Stem Cell Biology, Stanford University, Stanford, \\ California, USA, ${ }^{3}$ Stanford University School of Medicine, Stanford, California, USA and ${ }^{4}$ The Turek Clinic, \\ San Francisco, California, USA \\ Correspondence should be addressed to C M John; Email: connie@mandalmed.com
}

${ }^{\dagger}$ (M Gaur is now at Aelan Cell Technologies, Inc., San Francisco, CA, USA; C Ramathal is now at Abbvie Pharmaceuticals, North Chicago, IL, USA; and R A Reijo Pera is now at Montana State University, Bozeman, MT, USA

\begin{abstract}
Our overall goal is to create a three-dimensional human cell-based testicular model for toxicological and spermatogenesis studies. Methods to purify the major somatic testicular cells, namely Leydig cells (LCs), peritubular myoid cells (PCs) and Sertoli cells (SCs), from rats, mice and guinea pigs have been reported. In humans, the isolation of populations enriched for primary LCs, PCs or SCs also have described. One objective of this study was to determine if populations of cells enriched for all three of these cell types can be isolated from testes of single human donors, and we were successful in doing so from testes of three donors. Testes tissues were enzymatically digested, gravity sedimented and Percoll filtered to isolate populations enriched for LCs, PCs and SCs. LCs and PCs were identified by colorimetric detection of the expression of prototypical enzymes. Division of PCs and SCs in culture has been reported. We observed that primary human LCs could divide in culture by incorporation of 5-ethynyl-2'-deoxyuridine. SCs were identified and their functionality was demonstrated by the formation of tight junctions as shown by the expression of tight junction proteins, increased transepithelial electrical resistance, polarized secretion of biomolecules and inhibition of lucifer yellow penetration. Furthermore, we found that human SC feeder layers could facilitate germ cell progression of human embryonic stem cells (hESCs) by microarray analysis of gene expression.

Reproduction (2018) 155 151-164
\end{abstract}

\section{Introduction}

The process of spermatogenesis whereby spermatogonial stem cells give rise to spermatozoa is a robust yet disruptable cellular transformation capable of producing about 1000 sperm per second in men. Human germ cells undergo mitosis (spermatogonial proliferation), meiosis (spermatocyte DNA recombination, reduction and division) and spermiogenesis (differentiation of spermatids) over a period averaging 64 days (Misell et al. 2006). The process is defined by intricate signaling and precise cell-cell interactions. Thus, we postulate that development of a robust in vitro spermatogenesis model requires a multicellular milieu to effectively represent the testicular stem cell niche (Oatley \& Brinster 2012).

Here, we describe a protocol for the isolation of cell populations enriched for three major human testicular somatic cells, Leydig cells (LCs), peritubular myoid cells (PCs) and Sertoli cells (SCs) from testes of a single human donor. Previous studies have shown that human PCs proliferate in vitro (Schlatt et al. 1996,
Albrecht et al. 2006, Albrecht 2009). We have previously reported methodology that produces $>95 \%$ pure populations of proliferative primary SCs from cadaveric testis (Chui et al. 2011, Xiao et al. 2014). Herein, we demonstrated the potential of LCs to divide in culture by evaluating 5-ethynyl-2'-deoxyuridine (EdU) incorporation into DNA along with immunochemical staining of LC markers. SCs can form tight junctions (TJs) that can be shown immunohistochemically and can be analyzed by measurement of transepithelial electrical resistance (TER) when the cells are grown on transwell (TW) inserts. Long-term culture of SCs in vitro could be necessary to achieve human spermatogenesis; therefore, we tested the functionality of the SCs as indicated by the maintenance of TER in a 3-dimensional TW model for an extended period of time. We cultured the human SCs in 24-well plates with TW inserts and observed the formation of TJs for more than a month.

There has been progress in generation of male germ cells from stem cells including pluripotent stem cells toward better understanding of male infertility 
(Hou et al. 2014, Ishikura et al. 2016). In this study to further assess the functionality of the human SCs and the potential feasibility of in vitro human spermatogenesis, we compared germ cell differentiation of $\mathrm{H} 1$ human embryonic stem cells (hESCs) when cultured in primordial germ cell (PGC) medium supplemented with growth factors and hormones and growing adherently on either Matrigel (Corning) or on SC feeder layers. The feeder layers enhanced initial growth factorinduced germ cell differentiation, indicating that the SCs maintain functionality that may be essential for in vitro spermatogenesis (Huleihel et al. 2007). These data indicate that it could be feasible to develop a human multicellular in vitro model of spermatogenesis (Xiao et al. 2014) for reproductive toxicology.

\section{Materials and methods \\ Procurement of cadaveric testes}

Cadaveric testes from five deceased human males of 26-56 years of age were obtained within $36 \mathrm{~h}$ of death through protocols approved by the National Disease Research Interchange (www.ndriresource.org) in Philadelphia, PA, USA and the Donor Network West (www.donornetworkwest. org) in San Ramon, CA, USA. Donations were obtained with informed consent and were not accepted if there had been a history of testicular cancer. HIPAA regulations were followed for privacy protection.

\section{Isolation of human SCs and PCs}

The procedure was similar to that we previously reported for the isolation of SC-enriched populations of cells from testes of deceased human males between 12 and 36 years of age (Ketola et al. 2000, Chui et al. 2011) with modifications to enable simultaneous isolation of LCs and PCs (Lejeune et al. 1993, 1998, Cudicini et al. 1997). After washing each testis with ice-cold calcium/magnesium-free Hanks balanced salt solution (HBSS; Cell Culture Facility, University of California, San Francisco, CA, USA) containing $100 \mathrm{U} / \mathrm{mL}$ penicillin and $100 \mu \mathrm{g} / \mathrm{mL}$ streptomycin (HBSS with P/S), the tunica albuginea was removed, the parenchyma was thoroughly minced, and then transferred to a beaker. Minced tissue was pooled, suspended in $100 \mathrm{~mL}$ HBSS with $\mathrm{P} / \mathrm{S}$ and allowed to gravity sediment at room temperature (RT) for $15 \mathrm{~min}$ (Fig. 1). The supernatant was aspirated to remove germ cells and the gravity sedimentation step was repeated twice. After the final wash, HBSS with $\mathrm{P} / \mathrm{S}$ was added in a 3:1 volume ratio (HBSS:tissue), and the tissue was shaken in a water bath incubator at $275-325 \mathrm{rpm}$ at $37^{\circ} \mathrm{C}$ for $20 \mathrm{~min}$. The supernatant was discarded, and $80 \mathrm{~mL} \mathrm{HBSS}$ with P/S, $10 \mathrm{~mL}$ trypsin $(2.5 \%), 10 \mathrm{~mL}$ collagenase Type IV (1\%) and $2 \mathrm{~mL}$ DNase $(1.0 \mathrm{mg} / \mathrm{mL}$; all from Sigma-Aldrich) were added. The tissue was again shaken at $37^{\circ} \mathrm{C}$ but for only $5-15 \mathrm{~min}$, after which the digested solution was passed through a metal sieve to remove connective and undigested tissue. Based on the total volume, $0.1 \%$ soybean trypsin inhibitor (stock: $0.34 \%$; Sigma-Aldrich) was then added. The filtered solution was centrifuged at $200 \mathrm{~g}$ for $5 \mathrm{~min}$, and after discarding the supernatant, DMEM:F12 containing $100 \mathrm{U} / \mathrm{mL}$ penicillin and $100 \mu \mathrm{g} / \mathrm{mL}$ streptomycin (DMEM:F12 with P/S) was added in a 10:1 volume ratio (DMEM:tissue). The cell suspension was gravity sedimented at RT for $30 \mathrm{~min}$, and the supernatant enriched for interstitial cells was set aside for further isolation of LCs using Percoll gradient centrifugation. Sedimented tubular fragments $(\sim 20-30 \mathrm{~mL})$ were resuspended in 2 volumes of calcium and magnesium-free PBS (PBS-CMF) containing $1 \mathrm{M}$ glycine and $2 \mathrm{mM}$ EDTA $(\mathrm{pH} 7.4)$ and submitted to repeated pipetting for $10 \mathrm{~min}$ to remove PCs. Tubular fragments were isolated in two gravity sedimentations, and resulting supernatants enriched with PCs were pooled, centrifuged, plated and the cells were cultured in Minimum Essential Medium (MEM) with 10\% fetal bovine serum (FBS) and $\mathrm{P} / \mathrm{S}$. The pellets enriched for tubular fragments and SCs were plated and the cells were cultured in DMEM:F12 with $\mathrm{P} / \mathrm{S}$ and $10 \% \mathrm{FBS}$. Cell culture media were removed and fresh media was added every 2-3 days.

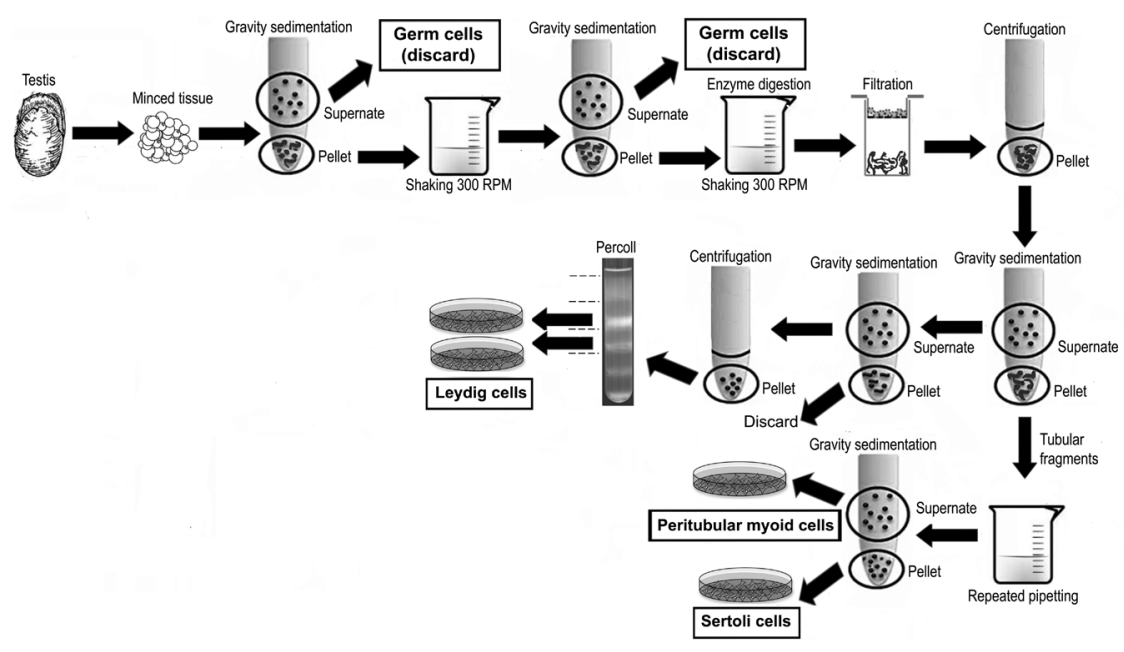

Figure $1 \mathrm{~A}$ schematic illustrating the methodology adapted from previous reports and used in isolation of cell populations (LCs, PCs and SCs) from human testis. Tissue was minced, shaken at $37^{\circ} \mathrm{C}$ and digested with enzymes. Several gravity sedimentation steps and a Percoll gradient were employed as illustrated. 


\section{Purification of human LCs on discontinuous Percoll gradient}

The fraction enriched for LCs and interstitial cells was subjected to gravity sedimentation for $15 \mathrm{~min}$. Then, LCs and interstitial cells were recovered from the supernatant by centrifugation ( $5 \mathrm{~min}, 200 \mathrm{~g}$ ), counted and a suspension of $10^{8}$ cells in $5 \mathrm{~mL}$ of DMEM:F12 with P/S was applied to a 4-layer discontinuous Percoll (GE Healthcare) gradient of 21, 26, 34 and $60 \%$ in PBS-CMF. After centrifugation at $1500 \mathrm{~g}$ for $30 \mathrm{~min}$, the cell bands from the second and third Percoll fraction (F2; between 26 and 34\%) and F3 (between 34 and $60 \%$ ) were collected separately, diluted with 2 volumes of DMEM:F12 with P/S, centrifuged at $200 \mathrm{~g}$ for $10 \mathrm{~min}$ and then plated and cultured in DMEM:F12 with P/S and 10\% FBS. Cell culture media was removed and fresh media was added every 2-3 days.

\section{Immunofluorescence staining for SCs}

For expression marker staining, passage 1 or 2 testicular cells were plated post isolation after becoming confluent (1-2 weeks), and then cultured for 3-4 days in chamber slides or glass coverslips in 12-well plates. For all other analyses, cells of passage $2-3$ were used. SCs $\left(2.5 \times 10^{4}\right)$ were plated in 8-well Nunc chamber slides (LabTek II, Nunc, Thermo Fisher Scientific) pre-coated with fibronectin (FN; $6.6 \mu \mathrm{g} / \mathrm{mL}$; Life Technologies). At $72 \mathrm{~h}$ post plating, cells were fixed with $4 \%$ paraformaldehyde (PFA; Thermo Fisher Scientific), permeabilized using 0.5\% Triton-X-100 (Sigma-Aldrich), blocked for $1 \mathrm{~h}$ in $10 \%$ normal goat serum and incubated with rabbit anti-GATA-4 (Table 1, Santa Cruz Biotechnology) followed by goat anti-rabbit Alexa Fluor 546 (Life Technologies). Images were acquired on a Nikon Eclipse E600 upright epifluorescence microscope (Histology and Light Microscopy Core Facility, Gladstone Institutes, San Francisco, CA, USA).

\section{Alkaline phosphatase staining for PCs}

The cells from PC-enriched supernatants were plated in a 12 -well plate $\left(3 \times 10^{5}\right.$ cells/well $)$ in MEM containing $10 \%$ FBS and $\mathrm{P} / \mathrm{S}$ and stained using a Vector Red Alkaline phosphate substrate kit (Vector Laboratories, Burlingame, CA, USA) according to the manufacturer's protocol.

Table 1 Antibodies used for experiments in this report.

\begin{tabular}{llllc}
\hline Target & Source & Host & Catalog no. & $\begin{array}{c}\text { Application } \\
\text { (s) }\end{array}$ \\
\hline GATA-4 & $\begin{array}{c}\text { Santa Cruz } \\
\text { Biotechnology }\end{array}$ & rabbit & Sc-9053 & ICC \\
calretinin & $\begin{array}{c}\text { Novus Biologicals } \\
\text { N-cadherin }\end{array}$ & rabbit & NBP2- & IHC, ICC \\
& $\begin{array}{c}\text { Santa Cruz } \\
\text { Biotechnology }\end{array}$ & rabbit & SC-7939 & IHC, WB \\
JAM-A & $\begin{array}{c}\text { Zymed Technologies/ } \\
\text { (JAM1) }\end{array}$ & rabbit & $36-1700$ & IHC, WB \\
ZO-1 & $\begin{array}{c}\text { Zymed Technologies/ } \\
\text { ThermoFisher }\end{array}$ & mouse & $33-9100$ & IHC, WB \\
\hline
\end{tabular}

\section{3ß-hydroxysteroid dehydrogenase staining of LCs}

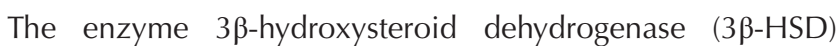
is an oxidoreductase that catalyzes the synthesis of progesterone from pregnenolone, 17-hydroxyprogesterone from 17-hydroxypregnenolone and androstenedione from dehydroepiandrosterone. Human LCs have been shown to express the type II $3 \beta-\mathrm{HSD}$ isoenzyme (Simpson et al. 1987, Ge et al. 2006). Staining for 3 $\beta$-HSD activity was performed as previously described (Klinefelter et al. 1987). LCs from F3 $\left(1 \times 10^{5}\right.$ cells/well $)$ were plated in 12-well plates. Dehydroepiandrosterone $(0.5 \mu \mathrm{g}$; Sigma-Aldrich) was added to a mixture of nitroblue tetrazolium and nicotinamide adenine dinucleotide (both Sigma-Aldrich) solutions $(1: 1 ; 1 \mathrm{mg} / \mathrm{mL}$ ) and mixed thoroughly. To each well, $500 \mu \mathrm{L}$ of the solution was added and the plate was incubated at $37^{\circ} \mathrm{C}$ for $1.5-3 \mathrm{~h}$.

\section{Immunofluorescence staining of LCs}

The LCs from F3 $\left(2.5 \times 10^{4}\right)$ were plated on 8-well Nunc chamber slides (Thermo Fisher Scientific). For staining, the cells were fixed with $4 \%$ PFA for $10 \mathrm{~min}$ and then permeabilized with $0.1 \%$ Triton-X-100 (Sigma-Aldrich). After blocking with $10 \%$ normal goat serum, cells were incubated with rabbit anti-calretinin (Table 1, Novus Biologicals, Littleton, CO, USA) followed by goat anti-rabbit Alexa Fluor 546 secondary antibody $(\mathrm{Ab})$. Sections of frozen human testis tissue were used as a positive control.

\section{Proliferation of SCs and LCs revealed by 5-ethynyl-2'- deoxyuridine ( $E d U)$ incorporation}

SCs and LCs from F3 $\left(1 \times 10^{4}\right)$ were plated on 8 -well Nunc chamber slides and incubated in $5 \% \mathrm{CO}_{2}$ at $37^{\circ} \mathrm{C}$ overnight. The next day, cells were stained using a Click-it EdU kit (Life Technologies/Thermo Fisher) per the manufacturer's recommendations. The cells were incubated in DMEM:F12 medium with EdU $(5 \mu \mathrm{M})$ overnight. To identify proliferating LCs, after incorporation of EdU, cells were stained using rabbit anti-calretinin (Table 1, Novus Biologicals), followed by staining with goat anti-rabbit Alexa Fluor 546 secondary Ab.

\section{TER measurements for evaluation of TJs of SCs}

Transwell inserts $\left(0.4 \mu \mathrm{m}\right.$ pore size, $0.33 \mathrm{~cm}^{2}$ surface area, PET, (Corning) for 24-well plates were coated with $100 \mu \mathrm{L}$ of PBS containing human $\mathrm{FN}(6.6 \mu \mathrm{g} / \mathrm{mL}$ in PBS-CMF) by incubation at $37^{\circ} \mathrm{C}$ overnight. SCs $\left(0.6-2.5 \times 10^{6} / \mathrm{cm}^{2}\right)$ were plated into the apical chamber in DMEM:F12 medium in $300 \mu \mathrm{L}$ DMEM:F12 medium with $10 \%$ FBS with $900 \mu \mathrm{L}$ medium placed in the basolateral chamber. The medium was changed every $48 \mathrm{~h}$. TER was measured using a Millicell-ERS Ohmmeter (EMD Millipore) equipped with an Ag/Ag electrode (STX2, World Precision Instruments, Sarasota, FL, USA). Readings were taken at three positions/well. At least three independent experiments were performed. TER values were calculated per $\mathrm{cm}^{2}$, and average TER of FN-coated control wells without cells was subtracted from the average TER of wells with cells. To determine if TER values were altered by SC concentration, we plated $0.6 \times 10^{6}$ 
and $1.5 \times 10^{6} \mathrm{SCs} / \mathrm{cm}^{2}$ in apical chambers of TW inserts in 24-well plates pre-coated with FN as described. To determine if TER values were altered by donor ages, populations enriched for SCs (MM-SC-1509, MM-SC-2305 and MM-SC-3608) that we had previously isolated from cadaveric tissue of deceased donors of 15, 23 and 36 years of age (Chui et al. 2011, Xiao et al. 2014) were plated in FN-coated TW inserts $\left(0.5 \times 10^{5}\right.$ cells/insert). We also tested a fibroblast cell line for use as a feeder layer that might promote TJ formation. HS-27 human foreskin fibroblasts (CRL-1634; ATCC) were plated $\left(2.5 \times 10^{5}\right)$ in the basolateral chambers of 24 -well TW inserts. The next day, the plated HS-27 cells were treated with mitomycin to prevent overgrowth. After washing, SCs were plated $\left(1 \times 10^{6} \%\right.$ $\mathrm{cm}^{2}$ ) in apical chambers pre-coated with FN. We determined whether HS-27 cells could form TJs when plated $\left(2.5 \times 10^{6}\right)$ on FN-coated TW inserts in which HS-27 cells were plated in the basolateral chamber. The HS-27 cells were treated with mitomycin as described earlier. To determine the effect of supplementation with $\mathrm{FSH}$ and testosterone, SCs were plated in TW inserts as described earlier in DMEM:F12 containing $10 \%$ FBS, $200 \mathrm{nM}$ testosterone (Sigma-Aldrich) and $1.36 \mathrm{IU} / \mathrm{mL}$ ( $100 \mathrm{ng} / \mathrm{mL})$ human FSH (Ferring Pharmaceuticals). To assess the susceptibility of the TJs to cadmium exposure, SCs were plated (MM-SC-4012, $1.5 \times 10^{6} / \mathrm{cm}^{2}$ ) in 24-well TW inserts in DMEM:F12 containing 10\% FBS supplemented with testosterone and FSH as described earlier. Cells in three wells were exposed to cadmium chloride $\left(\mathrm{CdCl}_{2}\right)$ at $10 \mu \mathrm{m}$ on day 12 and then to $30 \mu \mathrm{M}$ on day 14 . Cells in three other wells were exposed to $60 \mu \mathrm{M}$ on day 14 .

\section{Immunofluorescence staining of SCs and immunoblots of $T$ J proteins}

SCs $\left(1 \times 10^{6} / \mathrm{cm}^{2}\right)$ were plated on chamber slides (4-well) or glass coverslips that were coated with FN solution $(6.6 \mu \mathrm{g} / \mathrm{mL})$ overnight. The coverslips were placed in 12-well plates and the cells were cultured in DMEM containing $10 \%$ FBS at $37^{\circ} \mathrm{C}$ in $5 \% \mathrm{CO}_{2}$. For staining, the cells were washed and then fixed in $4 \%$ PFA in PBS-CMF, permeabilized with $0.5 \%$ Triton- $X$ 100 (Sigma-Aldrich) and stained with rabbit anti-N-Cadherin (Table 1, Santa Cruz Biotechnology), rabbit anti-JAM-A and mouse anti-ZO-1 (Table 1, both from Zymed Life Technologies, Waltham, MA, USA) antibodies followed by corresponding goat anti-rabbit Alexa Abs 546 and goat anti-mouse Alexa 488 (Life Technologies). Imaging was performed on a Zeiss confocal laser-scanning LSM510 meta (Laboratory for Cell Analysis, Helen Diller Cancer Center Core, University of California) or on a Nikon Eclipse E600 upright epifluorescence microscope (Histology and Light Microscopy Core Facility, Gladstone Institutes). For immunoblots of TJ proteins, SCs $\left(1.5 \times 10^{6} / \mathrm{cm}^{2}\right)$ were cultured on FN-coated TW inserts in 24-well plates for 8-12 days to ensure that TJ proteins were fully expressed. All reagents were from Thermo Fisher Scientific/Pierce unless indicated otherwise. The cells were rinsed with PBS-CMF and lysed using $1 \times$ RIPA buffer containing freshly added protease inhibitor cocktail and EDTA $(0.5 \mathrm{mM})$. Total protein was quantified by a Bradford assay (Thermo Fisher Scientific). Protein $(25 \mu \mathrm{g}$ total) in Laemmli loading buffer (Bio-Rad) was loaded onto 5-20\% SDS-PAGE gradient gels (Bio-Rad).
Proteins were electrophoresed at 200 volts and transferred using Midi transfer nitrocellulose membrane cassettes (BioRad) using a Trans-blot Turbo Transfer System (Bio-Rad) at 2.5 A constant current for $10 \mathrm{~min}$. Membranes were blocked with 5\% Blotto solution (Santa Cruz Biotechnology) and stained with primary antibodies (Table 1 ) at $4{ }^{\circ} \mathrm{C}$ overnight, followed by HRP-conjugated secondary antibodies at RT for $1 \mathrm{~h}$, and development using Supersignal Femto substrate.

\section{Lucifer yellow penetration assay}

SCs in DMEM:F12 media containing 10\% FBS were plated $\left(1.5 \times 10^{6} / \mathrm{cm}^{2}\right)$ in human FN-coated TW inserts in 24-well plates. A stock solution $(60 \mathrm{mM})$ was prepared by dissolving lucifer yellow (Sigma-Aldrich) in HBSS. Plates were incubated at $37^{\circ} \mathrm{C}$ in $5 \% \mathrm{CO}_{2}$ on an orbital shaker in a cell culture incubator. After 8-10 days, SCs were rinsed once with HBSS and then $300-\mu \mathrm{L}$ of the lucifer yellow stock solution was added to the apical chamber and $900-\mu \mathrm{L}$ of HBSS added to the basolateral compartment of each TW chamber. After 1-h incubation with shaking, media was collected from apical and basolateral compartments, and $100 \mu \mathrm{L}$ of the collected media was transferred to a 96-well plate and fluorescence was measured with $485 \mathrm{~nm}$ excitation and $540 \mathrm{~nm}$ emission on a Polarstar Galaxy microtiter plate reader (BMG Labtech, Cary, NC, USA). Each condition was tested with three replicates. Lucifer yellow penetrance of FN-coated TW inserts without any cells was used as a control.

\section{Analysis of secretion of inhibin $B$ and estradiol-17ß secretion by SCs and testosterone by LCs}

Enzyme immunoassay (EIA) kits were used to quantify inhibin $B$ and estradiol-17 $\beta$ (1,3,5-estratriene-3,17 $\beta$-diol; estradiol, estrogen) secretion by SCs from donors of 23, 36 and 40 years of age growing in TW inserts by analysis of conditioned media. Media was harvested from the apical and basolateral chambers, and the supernatants were stored at $-80^{\circ} \mathrm{C}$ after centrifugation at $2000 \mathrm{~g}$ for $5 \mathrm{~min}$. After thawing, aliquots of media from both chambers were analyzed by EIA. A competitive EIA kit for detection of human inhibin B was used according to the vendor's instructions (\#MBS700779; MyBioSource, San Diego, CA, USA) with detection at $450 \mathrm{~nm}$ on a Thermomax (Molecular Devices, Sunnyvale, CA, USA) plate reader. A standard curve for the log of the concentration of human inhibin B $(4-800 \mathrm{pg} / \mathrm{mL})$ vs optical density was employed, and samples were analyzed in triplicate. For detection of estradiol levels in conditioned media from apical and basolateral chambers of the SCs growing in TW inserts, we used a competitive EIA kit according to the vendor's directions (\#582251; Cayman Chemical). A standard curve derived from analysis of the estradiol standards $(6.6-4000 \mathrm{pg} / \mathrm{mL})$ as a logit $\mathrm{B} / \mathrm{B}_{0}$ was used and samples were analyzed in triplicate at $405 \mathrm{~nm}$. To compare the total amount of inhibin $B$ and estradiol secreted by the cells into the two chambers, the concentration detected in the apical media was divided by three since the volume was only $300 \mu \mathrm{L}$, whereas the volume of media in the basolateral chamber was $900 \mu \mathrm{L}$. Testosterone levels in media conditioned by LCs were measured by a 
competitive EIA according to the manufacturer's instructions (ElA kit \#582701; Cayman Chemical). This procedure was similar to that described earlier for the estradiol EIA kit, except testosterone standards $(3.9-500 \mathrm{pg} / \mathrm{mL})$ were used to create a standard curve. A standard curve as a logit $B / B_{0}$ was used to quantify testosterone levels in samples that were analyzed in triplicate at $405 \mathrm{~nm}$.

\section{Culture of human ESCs with SCs in vitro}

The method for differentiating pluripotent stem cell lines was derived from Ramathal and coworkers (2014). The hESC H1 cell line initially was maintained in feeder-free conditions on Matrigel and grown in mTESR pluripotency maintenance medium (Stemcell Technologies, Vancouver, BC, Canada). H1 hESCs were lentivirally transduced with a mCherry reporter under the control of an $\mathrm{EF} 1 \alpha$ promoter $(\mathrm{H} 1-\mathrm{mCH})$. Positively transduced cells were selected for by exposure to blasticidin ( $2 \mu \mathrm{g} / \mathrm{mL}$ ) for 7-10 days. For germline differentiation, embryoid bodies (EB) were formed from $\mathrm{H} 1$ cells in AggreWell plates (Stemcell Technologies) for standardization of EB size and quality. $\mathrm{H} 1-\mathrm{mCH}$ cells were exposed to BMP4 for $48 \mathrm{~h}$ during the EB formation period. Subsequently, EBs of approximately 500 cells each were plated on Matrigel-coated plates (adherent) or co-cultured in either small colonies (50-100 cells) or as single cells with SCs (MM-SC-1509) that were derived from the testes of a deceased donor of 15 years of age (Chui et al. 2011, Xiao et al. 2014). Individually cultured or co-cultured $\mathrm{H} 1-\mathrm{mCH}$ cells were differentiated in PGC medium (DMEM:F12 50:50 with 20\% Knockout Serum Replacement (Life Technologies) with or without supplementation with BMP4 $(50 \mathrm{ng} / \mathrm{mL})$, $50 \mathrm{ng} / \mathrm{mL}$ EGF (both from R\&D Biosystems), $2 \mathrm{ng} / \mathrm{mL}$ human recombinant leukemia inhibitory factor (hLIF; Millipore/EMD) and $10 \mathrm{nM}$ retinoic acid (RA, Sigma-Aldrich). For controls, undifferentiated $\mathrm{H} 1-\mathrm{mCH}$ cells grown in mTESR I medium (Stemcell Technologies) were also collected for analyses. Following differentiation for 7 days, all co-cultures were enzymatically dissociated with Accutase (MP Biomedical, Santa Ana, CA, USA), filtered and H1-mCherry-positive cells enriched and separated from co-cultures using fluorescenceactivated cell sorting (FACS) on a BD FACS ARIA instrument. Briefly, dead cells in the total population were gated out using forward and side scatter patterns as well DAPI staining intensity. Parental H1-mCherry hESC cells were used as a positive control to establish sorting gates for mCherry-positive and -negative cells. H1-mCherry-positive populations were directly sorted into single cell, 10-cell and 100-cell fractions in a 96-well PCR plate. All sorted cells were subjected to gene expression analysis.

\section{Gene expression and single-cell analysis}

After FACS of single cells into 96-well PCR plates, approximately $1 \mu \mathrm{g}$ total RNA from cells of each $\mathrm{H} 1$-mCherry-positive EB and colony of cells was reverse-transcribed using SuperScript III First-Strand Synthesis System (Life Technologies). RNA was isolated using $5 \mu \mathrm{L} /$ well of $2 \times$ CellsDirect Reaction Buffer supplemented with $0.1 \mathrm{nM}$ SUPERase-In (Life Technologies/ ThermoFisher). For microfluidic PCR analysis of EBs and single colony samples, cDNA was preamplified using a pooled mix of primer pairs (200 $\mathrm{nM}$ each) in a reaction containing $2.5 \mu \mathrm{L}$ TaqMan Pre-Amp master mix, $1.25 \mu \mathrm{L}$ pooled primer mix and $1.5 \mu \mathrm{L}$ cDNA. For single-cell RNA extracts, cDNA was preamplified in a reaction mix containing $5 \mu \mathrm{L}$ RNA extract, $0.2 \mu \mathrm{L}$ SuperScript III RT Platinum Taq Mix, $2.5 \mu \mathrm{L}$ pooled primer mix (200 nM) and 1.3 $\mu \mathrm{L}$ DNA suspension buffer $(10 \mathrm{mM}$ Tris, $\mathrm{pH}$ 8.0, $0.1 \mathrm{mM}$ EDTA). Digital quantitative PCR analysis was performed on the Biomark 96.96 microfluidic qPCR chip (Fluidigm). For EBs and colony samples, transcription levels were determined in triplicate reactions. Relative expression was determined by normalization to the geometric mean of 5-6 housekeeping genes with the formula $2^{- \text {(delta } C t)}$ as previously described (Ramathal et al. 2014). Single cells with failed or absent housekeeping gene expression and cells with Ct values greater than 25 cycles were excluded. For single cells, the relative expression of VASA across all the cells from each treatment condition was averaged. Finally, the fold-change of relative expression was determined by log conversion of normalized Ct values (power $=2$ ) and plotted in bar charts.

\section{Statistical analysis}

Multiple group comparisons were analyzed by 1- or 2-way ANOVA followed by Bonferroni's or Tukey's post hoc tests. Within-group comparisons were done using two-tailed $t$ tests. Data are expressed as mean \pm S.D. Significance was defined at $P<0.05$.

\section{Results}

\section{Isolation of human SCs, LCs and PCS}

We attempted to isolate SCs, LCs and PCs using a modification illustrated in Fig. 1 of methods described earlier (Lipshultz et al. 1982, Santiemma et al. 1992, Lejeune et al. 1993) from both cadaveric testes of five human donors ranging in age from 26 to 56 years. According to these previously described methods, the initial shaking step at $37^{\circ} \mathrm{C}$ at $275-325 \mathrm{rpm}$ for 20 min facilitated removal of germ cells after gravity sedimentation. In the subsequent enzymatic digestion, we reduced exposure to 5-10 min and added DNase (final concentration $20 \mu \mathrm{g} / \mathrm{mL}$ ) to isolate fragments of intact seminiferous tubules. Samples of the digestion were removed periodically to check the progress by phasecontrast microscopy. Previously, Lejeune and coworkers (1993) purified human LCs and PCs from human testicular cells using Percoll gradient centrifugation. We modified this protocol and successfully isolated relatively pure SC fractions (>95\%) and fractions enriched in LCs $(40-60 \%)$ and PCs (30-60\%) from testes of three of the human donors as shown by immunostaining (Figs 2 and 3). The composition of the testes from the donors appeared to be similar. We developed the methodology with the first two donor tissues and isolated SCs and PCs, but not LCs. Percentages of the cell types in the three populations were derived from 

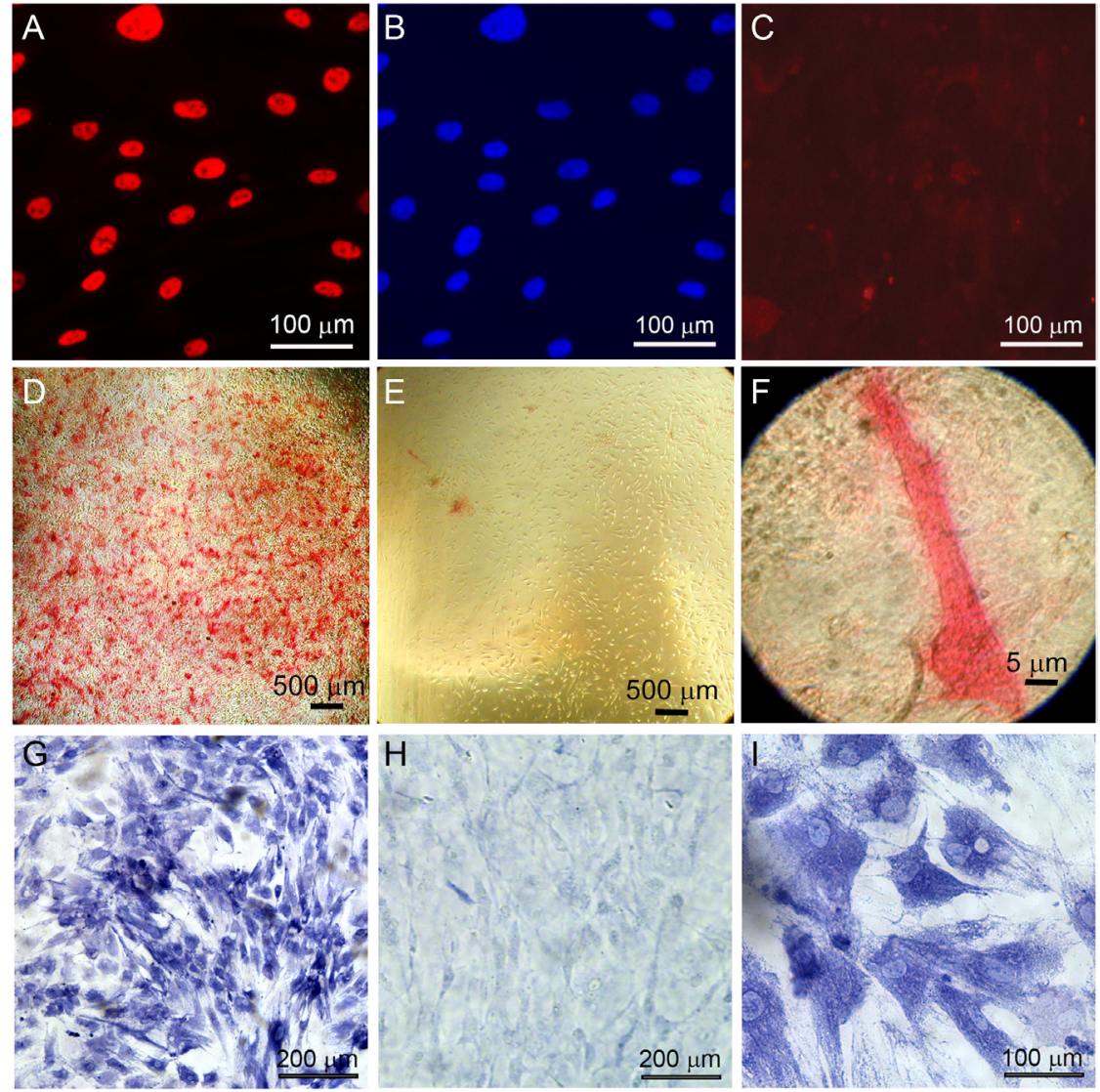

Figure 2 Images (A, B, C, D, E, F, G, H and I) of LCs, PCs and SCs isolated from a male donor of 56 years of age (MM-5613). All nuclei in the image of the SC-enriched popoulation were immunofluorescently stained for expression of GATA-4 (A) as revealed by blue nuclear DAPI staining $(\mathrm{B})$ and lack of red staining by secondary $\mathrm{Ab}$ alone $(\mathrm{C})$. Alkaline phosphatase activity is clearly shown by red staining in PC-enriched cells (D), and in a single cell (F), whereas the low level of red staining in the LC-enriched population (E) reveals paucity of $\mathrm{PC}$ cells with alkaline phosphatase activity. Blue staining ( $\mathrm{G}$ and I) revealed the activity of $3 \beta-H S D$ in $\mathrm{LCs}$ in fraction 3 and very limited $3 \beta-\mathrm{HD}$ activity $(\mathrm{H})$ in the SC-enriched fraction. immunohistochemistry by determining the number of the phenotypically stained cell type from the 3 different donors compared to the number of DAPI-stained nuclei in 3 fields of view. Although some LCs (20-30\%) were detected in F2, the population most enriched for LCs was recovered in $\mathrm{F} 3$ as reported previously (Lejeune et al. 1993). As we previously reported (Chui et al. 2011), immunocytochemistry showed that the majority $(>95 \%)$ of cells in SC-enriched population expressed GATA-4 (Fig. 2A; 2B presents nuclear DAPI staining and $2 \mathrm{C}$ is the secondary $\mathrm{Ab}$ alone control).

\section{Activity of alkaline phosphatase in PCs and 3ß-HSD in LCs}

Alkaline phosphatase is a known PC marker (Palombi \& Di Carlo 1988), and the cell population enriched for PCs demonstrated high alkaline phosphatase activity (Fig. 2D and F), whereas the LC-enriched population did not (Fig. 2E). As expected, the isolated LCs stained positively for $3 \beta-\mathrm{HSD}$ (Fig. $1 \mathrm{G}$ and $\mathrm{l} ; \mathrm{H}$ is the SC control).

\section{Human LCs and SCs proliferate in vitro}

The proliferation of cultured human LCs was shown by dual staining with $\mathrm{EdU}$ and calretinin, a marker for LCs (Augusto et al. 2002). Calretinin has been found to be expressed in the cytoplasm and in some of the nuclei of LCs (Augusto et al. 2002). We used staining of frozen sections of human testis (Fig $3 \mathrm{~A}$ and $\mathrm{B}$ ) to confirm the specificity of the calretinin Ab for LCs (Fig. 3B). The human testis sections were immunostained for expression of zonula occludens-1 (ZO-1), a TJ adaptor that is expressed by SCs and not by LCs. As another positive control, we analyzed the incorporation of EdU by proliferating human SCs co-immunostained for nuclear GATA-4 expression, as we previously described (Fig. 3C and D) (Chui et al. 2011). Dividing cells in F2 and F3 were identified by nuclear incorporation of EdU over $16 \mathrm{~h}$ followed by staining for calretinin to positively identify proliferating LCs (Fig. 3E). Positivity for calretinin in nuclei is indicated by the co-stained nuclear color (yellow-green) of proliferating calretininexpressing (red) cells compared to the nuclei (green) of proliferating cells not expressing calretinin (Fig. 3E and $\mathrm{F}$ ). The proportion of the total population in F3 that was actively dividing was revealed by simultaneously staining all nuclei with EdU and DAPI (Fig. $3 \mathrm{~F}$ and $\mathrm{H}$ ). In Fig. 3F several non-proliferating cells can be observed as DAPI-stained (blue) nuclei that are calretinin negative and also EdU negative and, therefore, are not observable in Fig. 3E. In Fig. $3 \mathrm{H}$ the proliferating co-stained cells in F3 have blue-green nuclei, whereas the nuclei of nondividing cells are blue due to only DAPI staining. 

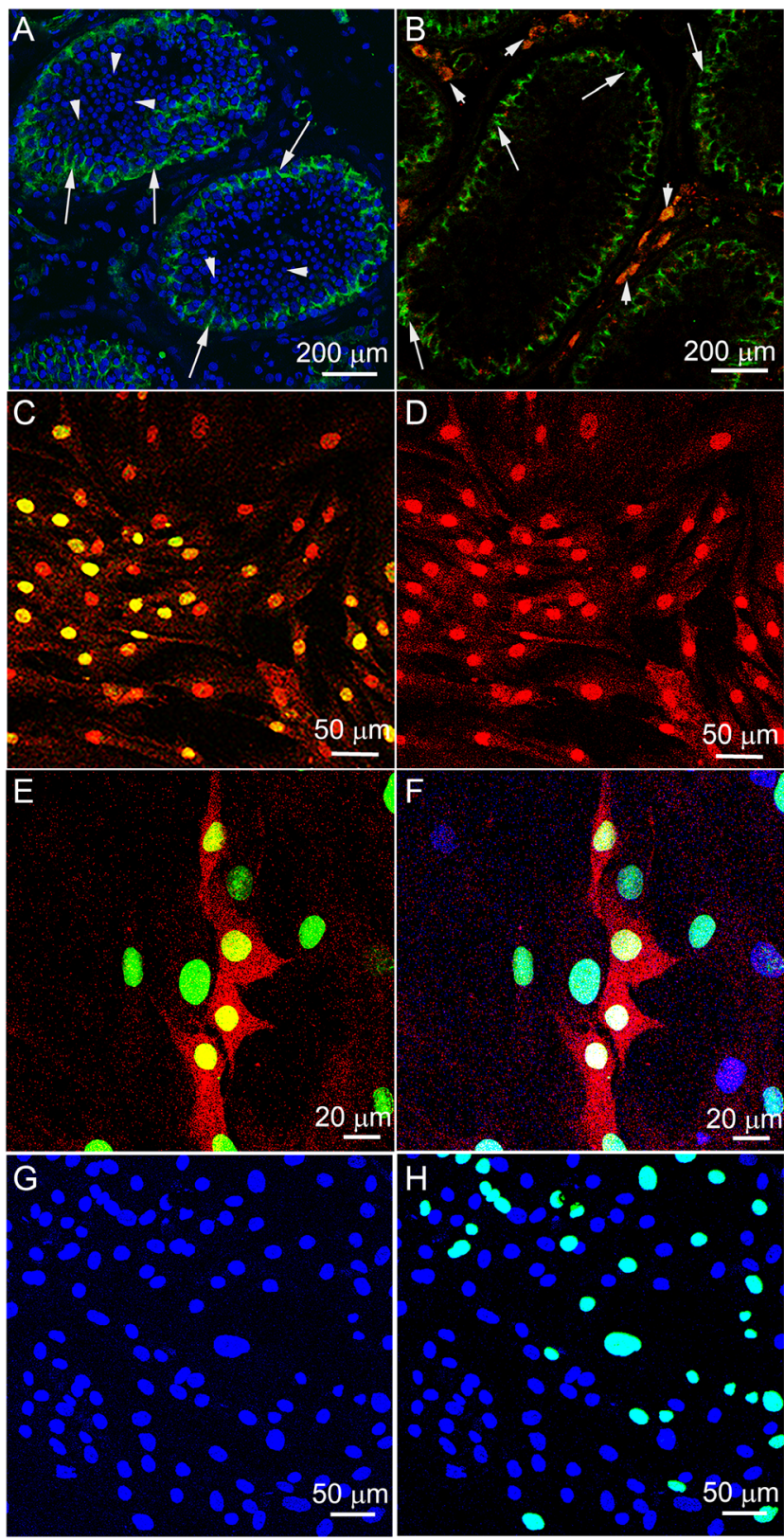

Figure $3(\mathrm{~A}, \mathrm{~B}, \mathrm{C}, \mathrm{D}, \mathrm{E}, \mathrm{F}, \mathrm{G}$ and $\mathrm{H})$ Primary SCs and LCs from a male donor of 40 years of age (MM-4012) divide in culture. Sections of human testis show seminiferous tubules revealed by

immunofluorescent staining of the TJ protein ZO-1 (A; green; arrows) and intrastitial LCs revealed by immunofluoresecent staining for calretinin expression (B, red; arrowheads). Actively dividing Sertoli cells from MM-SC-4012 are labeled with nuclear Click-it EdU signal (green) that co-stained with GATA4 signals (red; C and D) to create yellow (C). Cultured dividing LCs from MM-4012 immunostained for calretinin (red; $\mathrm{E}$ and $\mathrm{F}$ ) with nuclei stained green (E) with Click-It EdU or co-stained with Click-It EdU and DAPI (F). Cells from Fraction 3 of the Percoll gradient are shown stained for DAPI with $(\mathrm{H})$ and without (G) Click-It EdU green co-staining.

\section{SCs cultured on FN form and maintain TJs for more than 30 days}

After culture of populations enriched for hSCs on $\mathrm{FN}$-coated glass coverslips for $3-5$ days, immunostaining was performed for junctional adhesion molecule A (JAM-A), N-cadherin (a basal ectoplasmic specialization protein of adherens junctions) and ZO-1 (Fig. 4). The presence of TJ proteins at intracellular interfaces was revealed by positive immunocytochemistry (Fig. 4A, B and E) compared to controls stained with secondary $A b$ alone (Fig. 4C and E) as shown in the photomicrographs. Specificity of the Abs was shown by immunoblots of hSC populations after lysis (Fig. 4F), and ZO-1 staining of TJs in human testis sections (Fig. $3 \mathrm{~A}$ and $\mathrm{B}$ ).

We used the Millicell-ERS (Electrical Resistance System, EMD Millipore) to measure membrane potential and resistance of SCs cultured on TW inserts using a protocol described previously (Chung et al. 1999, Chung \& Cheng 2001, Chui et al. 2011). TER of $0.6 \times 10^{5}$ or $2.5 \times 10^{5}$ SCs was assessed in apical chambers on FN-coated TW inserts in 24-well plates with medium changes every $48 \mathrm{~h}$ (Chui et al. 2011). Elevated TER of SCs (Fig. 5A) was found to be between maintained at 50 and $90 \mathrm{ohms} / \mathrm{cm}^{2}$ until the experiment was stopped on day 35.

\section{TER of SCs from different donors on TW inserts is similar}

We compared TER of $5 \times 10^{5}$ SCs per well that were previously isolated from 3 different donors of 15, 23 and 36 years of age and found that all created TJs. Interestingly, although the TER of the SCs was similar, cells from the oldest donor, MM-SC-3608 (Fig. 5B), produced significantly higher TER $(P<0.001)$ than the other two cell populations.

\section{TER is reduced by cultures of SCs on HS-27 feeder layer in TW inserts}

We plated a layer $\left(2.5 \times 10^{5}\right)$ of human foreskin fibroblast cells (HS-27; CRL-1634; ATCC) into the basolateral chamber to determine the effect of bioactive molecules secreted by the cells such as FN (Zhang et al. 2012) on maintenance of TER by SCs that were plated in the apical chamber $\left(2.5 \times 10^{5}\right)$ on FN-coated TW inserts. The TER of HS-27 cells $\left(2.5 \times 10^{5}\right)$ plated in the apical chamber with HS-27 fibroblasts $\left(2.5 \times 10^{5}\right)$ plated in the basolateral chamber also was analyzed to determine if the HS-27 cells can form TJs as do the SCs. Prior to plating, HS27 cells were treated with mitomycin to prevent cell proliferation. The results (Fig. 5C) showed TER of SCs was reduced when HS-27 cells were present 

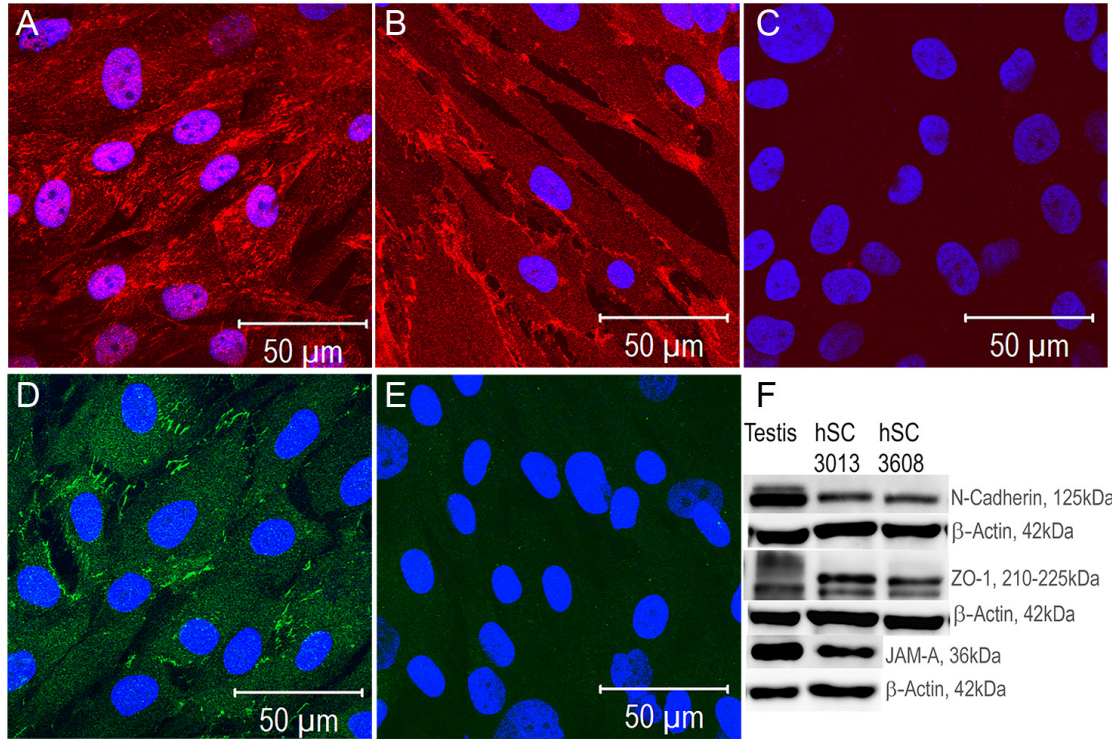

$\mathrm{F}$

Testis hSC hSC 30133608
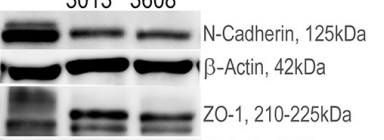

$\beta-A c t i n, 42 \mathrm{kDa}$

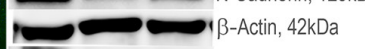

Figure 4 (A, B, C, D, E and F) SC-enriched populations from a male donor 40 years of age (MM-4012) cultured on FN-coated glass sides form TJs. Nuclei are blue stained with DAPI. Red immunostaining at intracellular interfaces shows expression of the TJ proteins JAM-A (A) and $\mathrm{N}$-cadherin (B) by the SCs. Immunostaining by the secondary $\mathrm{Ab}$ alone reveals lack of JAMA-A and $\mathrm{N}$-cadherin recognition $(C)$. Green immunostaining reveals ZO-1 expression (D). Immunostaining by secondary $\mathrm{Ab}$ alone reveals lack of $\mathrm{TJ}$ recognition (E). Immunoblots $(\mathrm{F})$ confirmed the specificity of the Abs to JAM-A, ZO-1 and $\mathrm{N}$-cadherin TJ proteins.
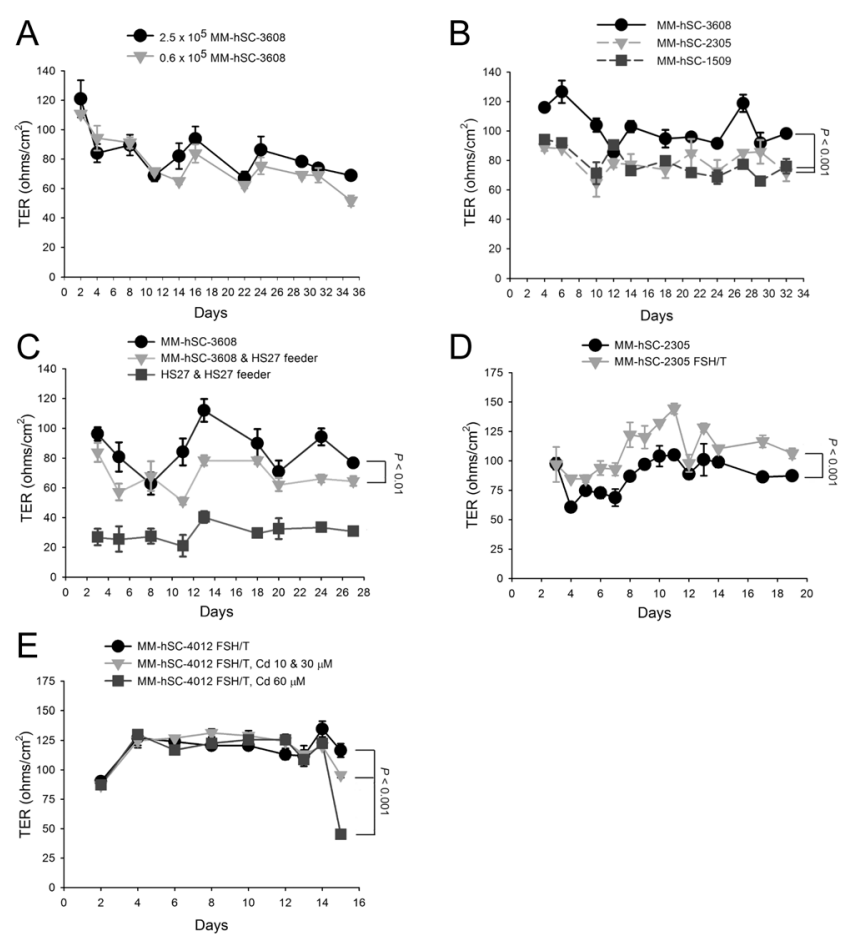

Figure 5 TER of SC-enriched populations on 24-well plate FN-coated TW inserts with $0.4 \mu \mathrm{M}$ pores for $20-36$ days (A, A, B, C, D and E). Variables are differing numbers of cells (A), SC-enriched populations from different donors (B), the addition of fibroblasts as feeders (C), FSH and testosterone treatment (D) and exposure of testosterone and FSH-treated SCs to $10 \mu \mathrm{M} \mathrm{CdCl}_{2}$ on day 12 and to $30 \mu \mathrm{M} \mathrm{CdCl}_{2}$ on day 14 and exposure of other SCs to $60 \mu \mathrm{M} \mathrm{CdCl}_{2}$ on day 14 (E). Averages shown are mean TER of cells in three TW insert chambers, and error bars are \pm S.D. Statistical significance was analyzed by ANOVA with Bonferroni's post hoc analysis.
A
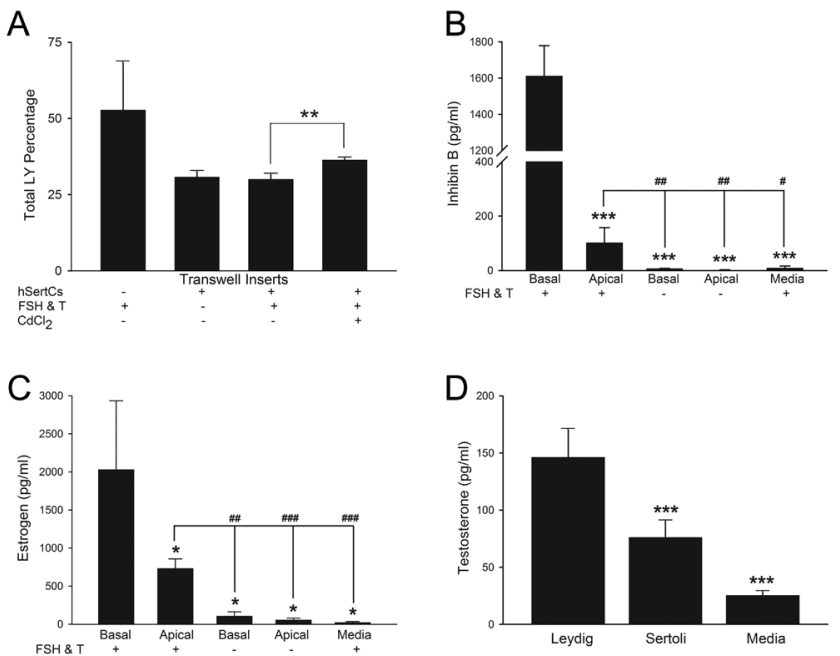

Figure 6 Percentage (A) of total apical lucifer yellow (LY, $60 \mu \mathrm{M})$ penetrating SCs from donors of 23 and 36 years of age on $\mathrm{FN}$-coated TW inserts (8- $\mu \mathrm{m}$ pores) compared to the percentage penetration of inserts with and without cells, FSH $(100 \mathrm{ng} / \mathrm{mL})$ and testosterone $(100 \mathrm{nM})$ or exposure to $30 \mu \mathrm{M} \mathrm{CdCl}_{2}$. Average penetration of FN-coated TW inserts was slightly $>50 \%$ of the total, and penetration was $\sim 30 \%$ in 3 wells with SCs $\left(2.5 \times 10^{5}\right.$ per well). Levels $(\mathrm{pg} / \mathrm{mL})$ of $(B)$ inhibin B in SC cells from donors of 23 and 30 years of age, and (C) estradiol in conditioned media from basal (basolateral) or apical chambers of TW inserts containing SCs from donors of 23, 30 and 36 years of age $\left(500,000\right.$ cells $/ 0.33 \mathrm{~cm}^{2}$ insert) with or without treatment by FSH $(100 \mathrm{ng} / \mathrm{mL})$ and testosterone $(100 \mathrm{nM})$ for $48 \mathrm{~h}$ or control media. Levels $(\mathrm{pg} / \mathrm{mL})$ of testosterone $(\mathrm{D})$ were quantified in conditioned media collected from confluent cultures of cells enriched for LCs and SCs after 3-4 days. For analysis of testosterone secretion, the LC-enriched populations were from donors of 40 and 56 years of age and the SC-enriched populations were from donors of 23 and 36 years of age. The level of testosterone detected in the unconditioned culture media (MEM with 10\% FBS) is shown as a control. All results are representative of 3 or more independent experiments and samples were analyzed in triplicate. Statistical significance of differences was analyzed by $T$ test $\left({ }^{\sharp} P<0.05,{ }^{* *}\right.$ and ${ }^{\sharp \sharp} P<0.01{ }^{* * *}$ and $\left.{ }^{\sharp \sharp \sharp} P<0.001\right)$. 
in the basolateral chamber of the TW insert during the culture $(P<0.01)$. Also, low TER showed that TJs were not formed when only HS-27 cells were plated on TW inserts.

\section{Supplementation of SCs with FSH and testosterone increases TER on TW inserts}

Treatment of SCs with media containing $200 \mathrm{nM}$ testosterone and $1.36 \mathrm{IU} / \mathrm{mL}(\sim 100 \mathrm{ng} / \mathrm{mL})$ human FSH (Ferring Pharmaceuticals) induced a statistically significant increase $(P<0.001)$ in TER (Fig. 5D).

\section{$\mathrm{CdCl}_{2}$ exposure reduces TER values}

The cells in three wells were treated with $10 \mu \mathrm{M} \mathrm{CdCl}_{2}$ on day 12 and then subsequently with $30 \mu \mathrm{M} \mathrm{CdCl}_{2}$ on day 14. Cells in a different set of three wells were treated with $60 \mu \mathrm{M} \mathrm{CdCl}_{2}$ on day 14 (Fig. 5E). Exposure to $10 \mu \mathrm{M} \mathrm{CdCl}$ did not reduce TER significantly. However, a significant decrease in TER was observed after exposure of cells to either $30 \mu \mathrm{M}$ or $60 \mu \mathrm{M} \mathrm{CdCl}_{2}$ (both $P<0.001$ compared to cells in unexposed wells) reflecting disruption of TJs.

\section{Monolayer of SCs on TW inserts reduced penetration of lucifer yellow}

The penetration of lucifer yellow in confluent SCs growing on $\mathrm{FN}$-coated TW inserts was assessed (Fig. 6A). Penetration of $180-\mu \mathrm{M}$ lucifer yellow placed in the apical chamber of FN-coated and -uncoated TW inserts in 24-well plates with and without SCs $\left(2.5 \times 10^{5}\right)$ at $37^{\circ} \mathrm{C}$ for $1 \mathrm{~h}$ was found to be $25.5,18.5$ and $13.7 \%$ in uncoated, FN-coated and FN-coated inserts with cells, respectively. To increase the penetration we tested the following: (i) lucifer yellow at 30 and $60 \mu \mathrm{M}$; (ii) 0.4 or $8.0 \mu \mathrm{m}$ pore size $\mathrm{FN}$-coated inserts (without cells) and (iii) incubation with shaking at $37^{\circ} \mathrm{C}$ for 1 or $2.5 \mathrm{~h}$. The greatest lucifer yellow penetration was in TW inserts of $8.0 \mu \mathrm{m}$ pores shaken for $1 \mathrm{~h}$ with $60 \mu \mathrm{M}$ lucifer yellow. Shaking for $2.5 \mathrm{~h}$ increased penetrance only slightly. Using these conditions, average penetration of TW inserts coated with $\mathrm{FN}$ alone was slightly more than $50 \%$ of the total. When SCs $\left(2.5 \times 10^{5}\right.$ per well $)$ were present penetration was reduced to $30 \%$. There was no change in penetration of the SCs when treated with $\mathrm{FSH}$ and testosterone, but lucifer yellow penetration significantly increased $(P<0.01)$ after exposure of SCs to $30 \mu \mathrm{M} \mathrm{CdCl}_{2}$.

\section{Treatment of human SCs with FSH and testosterone induced secretion of inhibin $B$ and estradiol}

Treatment with FSH and testosterone (7 $\beta$-hydroxy-3-oxo4 -androstene) greatly increased the secretion of inhibin $\mathrm{B}$ and estradiol (estrogen) by cultured adult SCs (Fig. 6B).
Inhibin B was virtually undetectable in wells with cells not treated with FSH and testosterone $(P<0.001)$. Our data also show that the secretion of inhibin $B$ was polarized with most occurring basolaterally and only 5 percent of the total secreted inhibin found in apical chambers of the TW inserts $(P<0.001)$. We observed that estradiol was secreted by human SCs cultured on TW inserts in the presence of exogenous FSH and testosterone (Fig. 6C) and that there was lower level of estradiol secreted by the SCs cultured in media in the absence of additional exogenous FSH and testosterone. More estradiol was secreted by hormone-treated SCs in the basolateral compared to the apical chambers.

\section{Human LCs secrete testosterone in vitro}

Our results show that cultures of testicular cells enriched for LCs in normal cell culture secreted testosterone (Fig. 6D), a hallmark of LCs.

\section{Primordial germ cell-like differentiation of H1 hESCs induced by culture on SC feeder layers}

SCs are somatic cells that make critical contributions to the testicular stem cell niche by the production of growth factors, nutrients, cytokines and immunosuppressive factors and maintenance of the blood-testis barrier (Petersen \& Soder 2006, Svingen \& Koopman 2013, Kaur et al. 2014). Primordial germ cell (PGC)-like differentiation of $\mathrm{H} 1$ hESCs was characterized by gene expression analysis after 7 days of culture as single cells, small colonies of 50-100 cells or as EBs with or without SC feeder layers and various growth factors (Fig. 7A). Supplements included in the media are critical for induction of mammalian germ cell differentiation; bone morphogenic protein (BMP)-4 (Kee et al. 2006), epidermal growth factor (EGF) (Yan et al. 1998), human leukemia inhibitory factor (hLIF) (Piquet-Pellorce et al. 2000, Dorval-Coiffec et al. 2005, Fukunaga et al. 2010) and RA (Gely-Pernot et al. 2012, Griswold et al. 2012). We also compared differentiation in PGC medium (DMEM:F12 with 20\% Knockout Serum Replacement) to that in mTESR medium (Stemcell Technologies).

We assessed the expression levels of a classical germ cell-specific lineage protein, VASA (DDX4), in mCherry-positive $\mathrm{H} 1$ cells after purifying them from heterogeneous cell mixtures using FACS (Fig. 7B). We observed the highest expression levels of VASA in $\mathrm{H} 1$ hESCs differentiating as colonies on SC feeder layers treated with RA, hLIF and BMP4. Highlighting the importance of $3 \mathrm{D}$ architecture in germ cell progression, relative VASA expression levels differed between single cells or colonies and EBs.

Previous studies have shown that germ cell progression of $\mathrm{hESC}$ is induced by overexpression of Dazl, Daz and Boule genes encoding germ-cellspecific cytoplasmic RNA-binding proteins. Human 


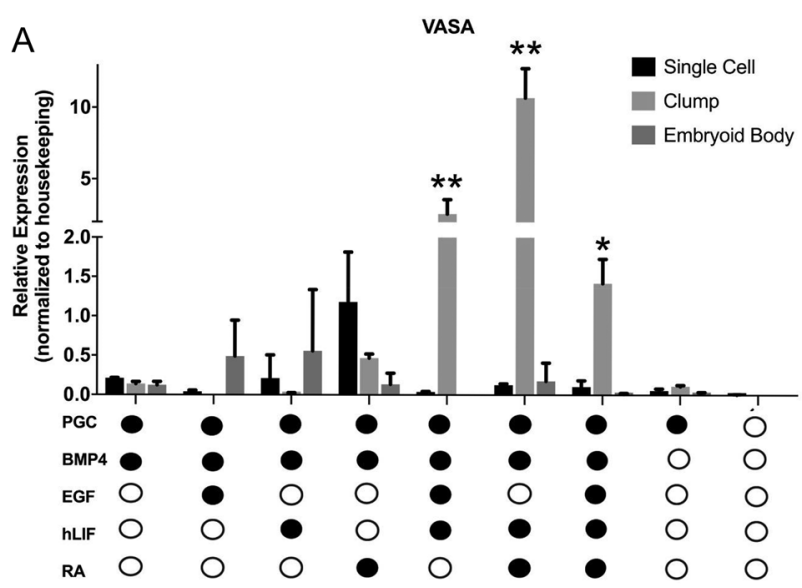

B

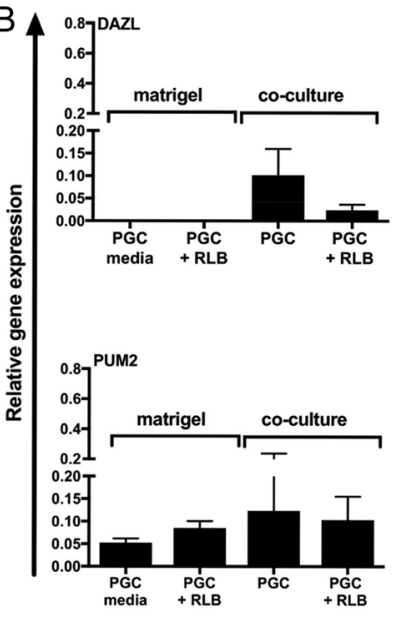

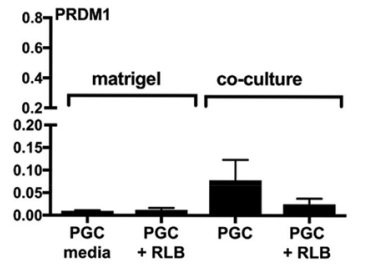
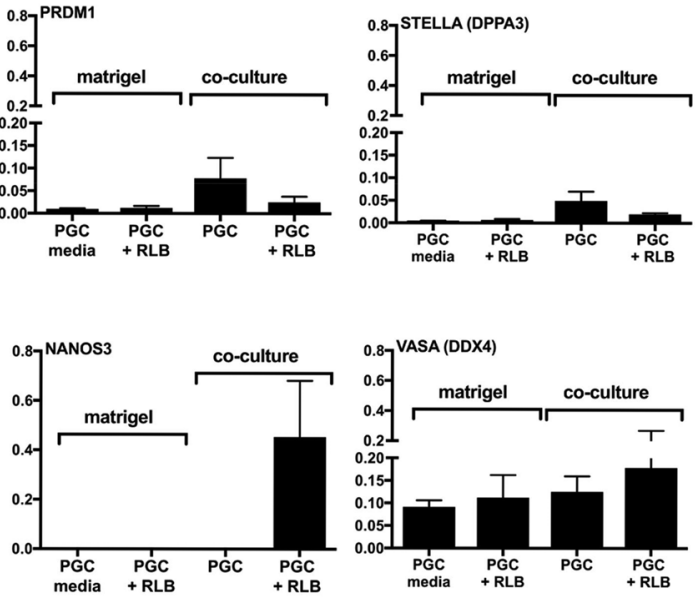

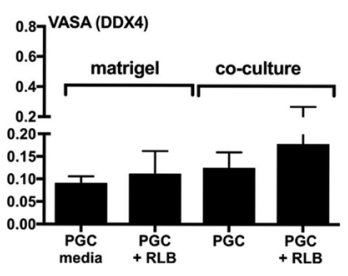

Figure 7 Gene expression analysis reveals co-culture of transduced $\mathrm{H} 1 \mathrm{hESC}$ s with human SCs from a donor 15 years of age increased PGC-like differentiation. (A) Microfluidic quantitative real-time PCR-based analysis of VASA gene expression in $\mathrm{H} 1 \mathrm{hESCs}$ differentiated on SC feeder layers as single cells, colonies of 50-100 cells or EBs, and supplemented with a variety of growth factors. Black ovals designate the presence of a factor or growth condition while white ovals indicate an absence of the factor/condition (A). Individual bar plots comparing the expression of genes indicative of germline formation in $\mathrm{H} 1 \mathrm{hESC}$ grown either as colonies (50100 cells) on Matrigel or as co-cultures with human SC feeder layers. All cultures were grown with and without RA, hLIF and BMP4 (RLB) supplementation as indicated in the plots (B). Error bars are \pm S.D. Statistical significance was analyzed by ANOVA. $* P<0.05$ and $* * P<0.001$.
Dazl expression induced PGC formation, and Daz and Boule expression promoted later stages of meiosis and development of haploid gametes (Kee et al. 2009). VASA is an ATP-dependent RNA helicase expressed by human germ cells that is most abundant in spermatocytes and mature oocytes (Castrillon et al. 2000, Noce et al. 2001). Overexpression of Vasa in induced pluripotent stems cells and in hESCs promotes progression to PGCs and to meiosis (Medrano et al. 2012).

Based on our observations of VASA expression, we chose to differentiate $\mathrm{H} 1 \mathrm{hESC}$ in a colony format with or without SC feeder layers and a cocktail of supplements that consisted of BMP4, hLIF and RA (Fig. 7B). Gene expression levels of Dazl, Prdm1, Stella (Dppa3), Nanos3, Pum2 and Vasa were tested in FACS-purified $\mathrm{H} 1$ cells after differentiation. The highest expression levels of Nanos 3 and Vasa were found in $\mathrm{H} 1$ hESCs differentiated on SC feeders and receiving the cocktail of supplements. Interestingly, the highest expression of Dazl, Prdm1, Pum2 and Stella was observed in $\mathrm{H} 1$ hESCs differentiated on SC feeder layers but without the supplementation of BMP4, hLIF and RA. Dazl, $\operatorname{Prdm} 1$ and Stella are characteristically expressed in PGCs that are the first cells committed to the germ cell lineage (Payer et al. 2006, Saiti \& Lacham-Kaplan 2007).
PDRM1 (also known as BLIMP1) is a transcriptional repressor that plays a role in the specification of the PGC population (Ohinata et al. 2005, Chu et al. 2011, Schafer et al. 2011).

\section{Discussion}

There is a long history of attempts to replicate spermatogenesis in vitro (Reuter et al. 2012). Most strategies have focused on organ culture of testes or testicular fragments but others have explored cell and tissue culture approaches. Spermatogenesis in vitro had only been achieved with certain species of fish until Sato and coworkers reported in a ground-breaking study that spermatogenesis in neonatal mouse testes, which contain only primitive germ cells, could be initiated an in vitro setting (Sato et al. 2011a,b). Fragments of testis tissue were maintained for over 2 months and the sperm produced was used in microinsemination to create healthy offspring. Shortly thereafter, complete spermatogenesis in vitro was achieved using cells isolated from enzymatically digested seminiferous tubules of 7-day-old mice cultured in a two-layer soft agar culture system (Abu Elhija et al. 2012, Mahmoud 2012). More recently, murine testicular cells including spermatozoa 
were propagated using spontaneous outgrowths of small pieces of seminiferous tubules (Mäkelä et al. 2014). Despite these promising accomplishments, derivation of mammalian spermatozoa in vitro remains difficult to achieve.

We are focused on the creation of the human testicular stem cell niche in vitro for modeling spermatogenesis. Here, we successfully isolated populations enriched for the three major somatic cell types, LCs, PCs and SCs (Svingen \& Koopman 2013) from testes of three human donor tissues. Immunocytochemistry showed that the majority (>95\%) of cells in the SC-enriched populations expressed GATA-4. Although GATA-4 is expressed in both SCs and LCs in testes of human adults (Ketola et al. 2000), there was very little $3 \beta-\mathrm{HSD}$ activity that is characteristic of LCs in the SC-enriched populations. Further evidence of the identity and phenotypical functionality of the SC-enriched populations in vitro was their expression of ZO-1, N-cadherin and JAM-A, and the polarized secretion of the biomolecules estradiol and inhibin B.

Contrary to the assumption that all LCs are essentially terminally differentiated cells, our data show that LCs could divide in culture. This result is consistent with the findings that adult rat LC regeneration occurs following destruction by ethane dimethane sulphonate (Teerds et al. 1999) and that proliferation of rodent LCs in vitro is enhanced by human chorionic gonadotropin exposure (Bi et al. 2011). Cultured LCs expressed both calretinin and the steroid-metabolizing enzyme, $3 \beta-H S D$, and prototypically secreted testosterone. The ability to propagate the LCs in culture should facilitate the creation of a multicellular model of spermatogenesis. Primary PCs previously were shown to retain the ability to proliferate in culture (Albrecht et al. 2006, Schell et al. 2008). We further confirmed our previous work that a population of SCs isolated from humans can retain the ability to divide in culture (Chui et al. 2011). Future studies will focus on characterizing genotypic and phenotypic changes in these populations of testicular cells with in vitro passage.

We previously found by measuring TER that human SCs form TJs when grown on TW inserts coated with FN but not with any other extracellular matrix coatings (Chui et al. 2011). Interestingly, $\mathrm{FN}$ is also secreted by PCs (Tung et al. 1984). Previous studies using SCs from rodents and humans have shown intracellular TJ formation and maintenance for approximately one week. Our results showed that primary hSCs maintained TJs in vitro for 35 days (when the experiment was stopped), far longer than previously thought possible. These data suggest that it is likely that TJs can be maintained by SCs in culture for even longer periods of time such as the 64-day average required for human spermatogenesis (Misell et al. 2006).

Our observation of increased inhibin B and estradiol secretion by the human SCs in response to FSH and testosterone treatment is supported by previous studies that have shown increased inhibin B secretion by FSH treatment of cultured rat SCs (Le Gac \& de Kretser 1982, Bicsak et al. 1987) and human SCs (Carreau 1995). The highest levels of inhibin B secretion by human SCs were detected in the basolateral chambers of the TWs, reflecting greater secretion out of, rather than into, the seminiferous tubule lumen. Inhibin B secretion by adult SCs and LCs modulates FSH secretion by the pituitary in a negative feedback loop (Griswold 1998). Serum inhibin B levels have been proposed as a biomarker for testicular toxicity and in combination with serum FSH levels, increased the predictive power for the detection of testicular damage over levels of either alone (Stewart \& Turner 2005). Polarized secretion of inhibin B by immature rat SCs in vitro has been reported but in these studies, apical levels were higher than the basolateral ones (Handelsman et al. 1989).

Supplementation with FSH and testosterone also induced secretion of estradiol by human SCs. Secretion of estradiol by cultured rat SCs has been induced by incubation with $\mathrm{FSH}$ in the presence of testosterone that is metabolized by SCs to estradiol (Dorrington \& Armstrong 1975, Fritz et al. 1976, Jannini et al. 1994). Testosterone treatment of human SCs cultured with FSH has also been shown to increase estradiol secretion (Foucault et al. 1992, 1994).

In previous studies, testosterone secretion increased in cultures of primary human LCs up to 12 days post isolation (Lejeune et al. 1998). We also found testosterone secretion by cell populations dominated by SCs, an effect likely due to the presence of LCs (Lejeune et al. 1998). We observed enhanced germ cell-like differentiation of cocktail-supplemented H1 hESCs grown on SC feeder layers compared to that of $\mathrm{H} 1 \mathrm{hESCs}$ differentiated without SC feeders. This promising finding demonstrates that in vitro cultures of SCs retain the ability to support germ cell differentiation. Furthermore, the differential expression profiles of $\mathrm{H} 1$ hESCs grown on SCs with or without BMP4, hLIF and RA supplementation, respectively, suggest that temporal modulation of external paracrine signals is necessary to provide the appropriate milieu for germ cell formation. Thus, our data show a retention of phenotypic and functional characteristics by SCs that may be permissive for in vitro germ cell progression through meiosis and spermiogenesis. In the future, we intend to correlate expression levels of phenotypic genetic or proteomic markers by the human SCs, LCs and PCs and cellular functions essential in the progression of germ cells (Com et al. 2014).

We observed higher germ cell gene expression profiles in the cell colonies compared to the EBs. We surmise that this is because the total area of contact between the SCs and hESCs in cell colonies is greater than that in EBs. Thus, the physical interactions and paracrine effects of co-cultured SCs could be enhanced when hESCs are 
grown as small colonies rather than as single cells or in larger, much denser EBs. It is possible that the cell relationship in colonies more closely recapitulates the in vivo relationship of SCs and germ cells and leads to more efficient induction of germ cell differentiation.

In the long term, we seek to create an in vitro model of spermatogenesis that can be used to assess the reproductive toxicology of chemicals and drugs. Most testicular toxicology is based on studies in animals, but an analysis of 150 pharmaceutical compounds in the development showed that the predictive value of studies using multiple mammalian species for revealing toxic effects in specific human organs was only $70 \%$. When studies were conducted in a single mammalian species, the predictive value falls to 7 and $27 \%$ with rodents or non-rodent mammals, respectively (Olson et al. 2000). Thus, there is a need for novel and more accurate models of toxicity, and specifically for testicular toxicity. In vitro bioassays are cost-effective compared to animal testing, and ethical concerns surrounding animal experimentation increase the attractiveness of in vitro testing.

In conclusion, we have described a protocol to isolate populations enriched for the 3 major somatic cell populations, LC, PCs and SCs, from the testes of a single human cadaver, and have shown that the LCs can divide in culture and have demonstrated retention of phenotypical functionality in early passage number $(1-3)$ cells. We also demonstrated that populations of primary hSCs maintained intact TJs in vitro for extended periods of time, and when used as feeder layers, induced germ cell lineage progression of hESCs. Overall, our results support the feasibility of creating a human testicular stem cell niche in vitro for application in modeling spermatogenesis.

\section{Declaration of interest}

M Gaur, P J Turek and C M John have equity in MandalMed that has pending U.S. patent (Application \#20090028833) on proliferative SCs. R A Reijo-Pera and P J Turek are co-inventors on a U.S. patent for methodology to produce pluripotent human spermatogonial stem cells (US Patent $\# 8,673,637$ ). There are no other conflicting interests with the study.

\section{Funding}

This study was supported by a grant from the National Institute of Environmental Health Sciences of the NIH (1R43ES019824) awarded to C M John and P J Turek.

\section{Author contribution statement}

M Gaur, C Ramathal and C M John conducted laboratory experiments, generated and analyzed data and prepared the manuscript. R Reijo-Pera and P J Turek contributed materials.
C M John, P J Turek and R Reijo-Pera conceived of the study, participated in analysis and interpretation of data and writing and final approval of manuscript.

\section{References}

Abu Elhija M, Lunenfeld E, Schlatt S \& Huleihel M 2012 Differentiation of murine male germ cells to spermatozoa in a soft agar culture system. Asian Journal of Andrology 14 285-293. (https://doi.org/10.1038/ aja.2011.112)

Albrecht M 2009 Insights into the nature of human testicular peritubular cells. Annals of Anatomy 191 532-540. (https://doi.org/10.1016/j. aanat.2009.08.002)

Albrecht M, Ramsch R, Kohn FM, Schwarzer JU \& Mayerhofer A 2006 Isolation and cultivation of human testicular peritubular cells: a new model for the investigation of fibrotic processes in the human testis and male infertility. Journal of Clinical Endocrinology and Metabolism 91 1956-1960. (https://doi.org/10.1210/jc.2005-2169)

Augusto D, Leteurtre E, De La Taille A, Gosselin B \& Leroy X 2002 Calretinin: a valuable marker of normal and neoplastic Leydig cells of the testis. Applied Immunohistochemistry and Molecular Morphology $\mathbf{1 0}$ 159-162.

Bi HD, Wang XY, Zhou GD, Liu W, Li M \& Xing X 2011 In vitro proliferation of rat Leydig cells. Zhonghua Nan Ke Xue 17 104-109.

Bicsak TA, Vale W, Vaughan J, Tucker EM, Cappel S \& Hsueh AJ 1987 Hormonal regulation of inhibin production by cultured Sertoli cells. Molecular and Cellular Endocrinology 49 211-217. (https://doi. org/10.1016/0303-7207(87)90215-2)

Carreau S 1995 Human Sertoli cells produce inhibin in vitro: an additional marker to assess the seminiferous epithelium development. Human Reproduction 10 1947-1949. (https://doi.org/10.1093/oxfordjournals. humrep.a136213)

Castrillon DH, Quade BJ, Wang TY, Quigley C \& Crum CP 2000 The human VASA gene is specifically expressed in the germ cell lineage. PNAS 97 9585-9590. (https://doi.org/10.1073/pnas.160274797)

Chu LF, Surani MA, Jaenisch R \& Zwaka TP 2011 Blimp1 expression predicts embryonic stem cell development in vitro. Current Biology 21 1759-1765. (https://doi.org/10.1016/j.cub.2011.09.010)

Chui C, Trivedi A, Cheng CY, Cherbavaz DB, Dazin PF, Huynh ALT, Mitchell JB, Rabinovich GA, Noble-Haeusslein LJ \& John CM 2011 Characterization and functionality of proliferative human Sertoli cells. Cell Transplant 20 619-635. (https://doi.org/10.3727/09636891 0X536563)

Chung NP \& Cheng CY 2001 Is cadmium chloride-induced inter-sertoli tight junction permeability barrier disruption a suitable in vitro model to study the events of junction disassembly during spermatogenesis in the rat testis? Endocrinology 142 1878-1888. (https://doi.org/10.1210/ endo.142.5.8145)

Chung SS, Lee WM \& Cheng CY 1999 Study on the formation of specialized inter-Sertoli cell junctions in vitro. Journal of Cellular Physiology $181 \quad 258-272 . \quad$ (https://doi.org/10.1002/(SICI)10974652(199911)181:2<258::AID-JCP8>3.0.CO;2-Q)

Cudicini C, Lejeune H, Gomez E, Bosmans E, Ballet F, Saez J \& Jegou B 1997 Human Leydig cells and Sertoli cells are producers of interleukins- 1 and -6. Journal of Clinical Endocrinology and Metabolism 82 1426-1433. (https://doi.org/10.1210/jcem.82.5.3938)

Dorrington JH \& Armstrong DT 1975 Follicle-stimulating hormone stimulates estradiol-17beta synthesis in cultured Sertoli cells. PNAS 72 2677-2681. (https://doi.org/10.1073/pnas.72.7.2677)

Dorval-Coiffec I, Delcros JG, Hakovirta H, Toppari J, Jegou B \& PiquetPellorce C 2005 Identification of the leukemia inhibitory factor cell targets within the rat testis. Biology of Reproduction 72 602-611. (https://doi.org/10.1095/biolreprod.104.034892)

Foucault P, Carreau S, Kuczynski W, Guillaumin JM, Bardos P \& Drosdowsky MA 1992 Human Sertoli cells in vitro. Lactate, estradiol-17 beta and transferrin production. Journal of Andrology 13 361-367.

Foucault P, Drosdowsky MA \& Carreau S 1994 Germ cell and Sertoli cell interactions in human testis: evidence for stimulatory and inhibitory effects. Human Reproduction 9 2062-2068. (https://doi.org/10.1093/ oxfordjournals.humrep.a138394) 
Fritz IB, Griswold MD, Louis BG \& Dorrington JH 1976 Similarity of responses of cultured Sertoli cells to cholera toxin and FSH. Molecular and Cellular Endocrinology 5 289-294. (https://doi.org/10.1016/03037207(76)90090-3)

Fukunaga N, Teramura T, Onodera Y, Takehara T, Fukuda K \& Hosoi Y 2010 Leukemia inhibitory factor (LIF) enhances germ cell differentiation from primate embryonic stem cells. Cell Reprogram 12 369-376. (https://doi. org/10.1089/cell.2009.0097)

Ge RS, Dong Q, Sottas CM, Papadopoulos V, Zirkin BR \& Hardy MP 2006 In search of rat stem Leydig cells: identification, isolation, and lineagespecific development. PNAS 103 2719-2724. (https://doi.org/10.1073/ pnas.0507692103)

Gely-Pernot A, Raverdeau M, Celebi C, Dennefeld C, Feret B, Klopfenstein M, Yoshida S, Ghyselinck NB \& Mark M 2012 Spermatogonia differentiation requires retinoic acid receptor gamma. Endocrinology 153 438-449. (https://doi.org/10.1210/en.2011-1102)

Griswold MD 1998 The central role of Sertoli cells in spermatogenesis. Seminars in Cell and Developmental Biology 9 411-416. (https://doi. org/10.1006/scdb.1998.0203)

Griswold MD, Hogarth CA, Bowles J \& Koopman P 2012 Initiating meiosis: the case for retinoic acid. Biology of Reproduction 8635.

Handelsman DJ, Spaliviero JA, Kidston E \& Robertson DM 1989 Highly polarized secretion of inhibin by Sertoli cells in vitro. Endocrinology 125 721-729. (https://doi.org/10.1210/endo-125-2-721)

Hou J, Yang S, Yang H, Liu Y, Liu Y, Hai Y, Chen Z, Guo Y, Gong Y, Gao WQ et al. 2014 Generation of male differentiated germ cells from various types of stem cells. Reproduction 147 R179-R188. (https://doi. org/10.1530/REP-13-0649)

Huleihel M, Abuelhija M \& Lunenfeld E 2007 In vitro culture of testicular germ cells: regulatory factors and limitations. Growth Factors 25 236-252. (https://doi.org/10.1080/08977190701783400)

Ishikura Y, Yabuta Y, Ohta H, Hayashi K, Nakamura T, Okamoto I, Yamamoto T, Kurimoto K, Shirane K, Sasaki H et al. 2016 In vitro derivation and propagation of spermatogonial stem cell activity from mouse pluripotent stem cells. Cell Reports 17 2789-2804. (https://doi. org/10.1016/j.celrep.2016.11.026)

Jannini EA, Ulisse S, Cecconi S, Cironi L, Colonna R, D'Armiento M, Santoni A \& Cifone MG 1994 Follicle-stimulating hormone-induced phospholipase A2 activity and eicosanoid generation in rat Sertoli cells. Biology of Reproduction 51 140-145. (https://doi.org/10.1095/ biolreprod51.1.140)

Kaur G, Thompson LA \& Dufour JM 2014 Sertoli cells - immunological sentinels of spermatogenesis. Seminars in Cell and Developmental Biology. 30 36-44 (https://doi.org/10.1016/j.semcdb.2014.02.011)

Kee K, Gonsalves JM, Clark AT \& Pera RA 2006 Bone morphogenetic proteins induce germ cell differentiation from human embryonic stem cells. Stem Cells and Development 15 831-837. (https://doi.org/10.1089/ scd.2006.15.831)

Kee K, Angeles VT, Flores M, Nguyen HN \& Reijo Pera RA 2009 Human DAZL, DAZ and BOULE genes modulate primordial germcell and haploid gamete formation. Nature 462 222-225. (https://doi. org/10.1038/nature08562)

Ketola I, Pentikainen V, Vaskivuo T, Ilvesmaki V, Herva R, Dunkel L, Tapanainen JS, Toppari J \& Heikinheimo M 2000 Expression of transcription factor GATA-4 during human testicular development and disease. Journal of Clinical Endocrinology and Metabolism 85 3925-3931. (https://doi.org/10.1210/jcem.85.10.6900)

Klinefelter GR, Hall PF \& Ewing LL 1987 Effect of luteinizing hormone deprivation in situ on steroidogenesis of rat Leydig cells purified by a multistep procedure. Biology of Reproduction 36 769-783. (https://doi. org/10.1095/biolreprod36.3.769)

Le Gac F \& de Kretser DM 1982 Inhibin production by Sertoli cell cultures. Molecular and Cellular Endocrinology 28 487-498. (https://doi. org/10.1016/0303-7207(82)90141-1)

Lejeune H, Skalli M, Sanchez P, Avallet O \& Saez JM 1993 Enhancement of testosterone secretion by normal adult human Leydig cells by coculture with enriched preparations of normal adult human Sertoli cells. International Journal of Andrology 16 27-34. (https://doi. org/10.1111/j.1365-2605.1993.tb01149.x)

Lejeune H, Sanchez P \& Saez JM 1998 Enhancement of long-term testosterone secretion and steroidogenic enzyme expression in human Leydig cells by co-culture with human Sertoli cell-enriched preparations.
International Journal of Andrology 21 129-140. (https://doi.org/10.1111/ j.1365-2605.1998.00105.x)

Lipshultz LI, Murthy L \& Tindall DJ 1982 Characterization of human Sertoli cells in vitro. Journal of Clinical Endocrinology and Metabolism $\mathbf{5 5}$ 228-237. (https://doi.org/10.1210/jcem-55-2-228)

Mahmoud H 2012 Concise review: spermatogenesis in an artificial threedimensional system. Stem Cells 30 2355-2360. (https://doi.org/10.1002/ stem.1238)

Mäkelä JA, Toppari J, Rivero-Muller A \& Ventela S 2014 Reconstruction of mouse testicular cellular microenvironments in long-term seminiferous tubule culture. PLoS ONE 9 e90088. (https://doi.org/10.1371/journal. pone.0090088)

Medrano JV, Ramathal C, Nguyen HN, Simon C \& Reijo Pera RA 2012 Divergent RNA-binding proteins, DAZL and VASA, induce meiotic progression in human germ cells derived in vitro. Stem Cells $\mathbf{3 0}$ 441-451. (https://doi.org/10.1002/stem.1012)

Misell LM, Holochwost D, Boban D, Santi N, Shefi S, Hellerstein MK \& Turek PJ 2006 A stable isotope-mass spectrometric method for measuring human spermatogenesis kinetics in vivo. Journal of Urology 175 242-246. (https://doi.org/10.1016/S0022-5347(05)00053-4)

Noce T, Okamoto-Ito S \& Tsunekawa N 2001 Vasa homolog genes in mammalian germ cell development. Cell Structure and Function 26 131-136. (https://doi.org/10.1247/csf.26.131)

Oatley JM \& Brinster RL 2012 The germline stem cell niche unit in mammalian testes. Physiological Reviews 92 577-595. (https://doi. org/10.1152/physrev.00025.2011)

Ohinata Y, Payer B, O'Carroll D, Ancelin K, Ono Y, Sano M, Barton SC, Obukhanych T, Nussenzweig M, Tarakhovsky A et al. 2005 Blimp1 is a critical determinant of the germ cell lineage in mice. Nature $\mathbf{4 3 6}$ 207-213. (https://doi.org/10.1038/nature03813)

Olson H, Betton G, Robinson D, Thomas K, Monro A, Kolaja G, Lilly P, Sanders J, Sipes G, Bracken W et al. 2000 Concordance of the toxicity of pharmaceuticals in humans and in animals. Regulatory Toxicology and Pharmacology 32 56-67. (https://doi.org/10.1006/ rtph.2000.1399)

Palombi F \& Di Carlo C 1988 Alkaline phosphatase is a marker for myoid cells in cultures of rat peritubular and tubular tissue. Biology of Reproduction 39 1101-1109. (https://doi.org/10.1095/biolreprod39.5.1101)

Payer B, Chuva de Sousa Lopes SM, Barton SC, Lee C, Saitou M \& Surani MA 2006 Generation of stella-GFP transgenic mice: a novel tool to study germ cell development. Genesis 44 75-83. (https://doi. org/10.1002/gene.20187)

Petersen C \& Soder O 2006 The Sertoli cell - a hormonal target and 'super' nurse for germ cells that determines testicular size. Hormone Research 66 153-161. (https://doi.org/10.1159/000094142)

Com EMelaine N, Chalmel F, \& Pineau C 2014 Proteomics and integrative genomics for unraveling the mysteries of spermatogenesis: the strategies of a team. Journal of Proteomics 107 128-143. (https://doi.org/10.1016/j. jprot.2014.04.013)

Piquet-Pellorce C, Dorval-Coiffec I, Pham MD \& Jegou B 2000 Leukemia inhibitory factor expression and regulation within the testis. Endocrinology 141 1136-1141. (https://doi.org/10.1210/endo.141.3.7399)

Ramathal C, Durruthy-Durruthy J, Sukhwani M, Arakaki JE, Turek PJ, Orwig KE \& Reijo Pera RA 2014 Fate of iPSCs derived from azoospermic and fertile men following xenotransplantation to murine seminiferous tubules. Cell Reports 7 1284-1297. (https://doi.org/10.1016/j. celrep.2014.03.067)

Reuter K, Schlatt S, Ehmcke J \& Wistuba J 2012 Fact or fiction: in vitro spermatogenesis. Spermatogenesis 2 245-252. (https://doi.org/10.4161/ spmg.21983)

Saiti D \& Lacham-Kaplan O 2007 Mouse germ cell development in-vivo and in-vitro. Biomark Insights 2 241-252. (https://doi. org/10.1177/117727190700200024)

Santiemma V, Rosati P, Guerzoni C, Mariani S, Beligotti F, Magnanti M, Garufi G, Galoni T \& Fabbrini A 1992 Human Sertoli cells in vitro: morphological features and androgen-binding protein secretion. Journal of Steroid Biochemistry and Molecular Biology 43 423-429. (https://doi. org/10.1016/0960-0760(92)90080-3)

Sato T, Katagiri K, Gohbara A, Inoue K, Ogonuki N, Ogura A, Kubota Y \& Ogawa T 2011a In vitro production of functional sperm in cultured neonatal mouse testes. Nature 471 504-507. (https://doi.org/10.1038/ nature09850) 
Sato T, Katagiri K, Yokonishi T, Kubota Y, Inoue K, Ogonuki N, Matoba S, Ogura A \& Ogawa T $2011 b$ In vitro production of fertile sperm from murine spermatogonial stem cell lines. Nature Communications 2472. (https://doi.org/10.1038/ncomms1478)

Schafer S, Anschlag J, Nettersheim D, Haas N, Pawig L \& Schorle H 2011 The role of BLIMP1 and its putative downstream target TFAP2C in germ cell development and germ cell tumours. International Journal of Andrology 34 e152-e158. (https://doi.org/10.1111/j.13652605.2011.01167.x)

Schell C, Albrecht M, Mayer C, Schwarzer JU, Frungieri MB \& Mayerhofer A 2008 Exploring human testicular peritubular cells: identification of secretory products and regulation by tumor necrosis factor-alpha. Endocrinology 149 1678-1686. (https://doi.org/10.1210/ en.2007-1064)

Schlatt S, de Kretser DM \& Loveland KL 1996 Discriminative analysis of rat Sertoli and peritubular cells and their proliferation in vitro: evidence for follicle-stimulating hormone-mediated contact inhibition of Sertoli cell mitosis. Biology of Reproduction 55 227-235. (https://doi.org/10.1095/ biolreprod55.2.227)

Simpson BJ, Wu FC \& Sharpe RM 1987 Isolation of human Leydig cells which are highly responsive to human chorionic gonadotropin. Journal of Clinical Endocrinology and Metabolism 65 415-422. (https://doi. org/10.1210/jcem-65-3-415)

Stewart J \& Turner KJ 2005 Inhibin B as a potential biomarker of testicular toxicity. Cancer Biomarkers 1 75-91. (https://doi.org/10.3233/CBM2005-1109)

Svingen T \& Koopman P 2013 Building the mammalian testis: origins, differentiation, and assembly of the component cell populations. Genes and Development 27 2409-2426. (https://doi.org/10.1101/ gad.228080.113)

Teerds KJ, de Boer-Brouwer M, Dorrington JH, Balvers M \& Ivell R 1999 Identification of markers for precursor and leydig cell differentiation in the adult rat testis following ethane dimethyl sulphonate administration. Biology of Reproduction 60 1437-1445. (https://doi.org/10.1095/ biolreprod60.6.1437)

Tung PS, Skinner MK \& Fritz IB 1984 Fibronectin synthesis is a marker for peritubular cell contaminants in Sertoli cell-enriched cultures. Biology of Reproduction 30 199-211. (https://doi.org/10.1095/ biolreprod30.1.199)

Xiao X, Mruk DD, Tang El, Wong CKC, Lee WM, John CJ, Turek PJ, Silvestrini B \& Cheng CY 2014 Environmental toxicants perturb Q1 human Sertoli cell adhesive function via changes in F-actin organization mediated by actin regulatory proteins. Human Reproduction 29 1279-1291. (https://doi.org/10.1093/humrep/deu011)

Yan YC, Sun YP \& Zhang ML 1998 Testis epidermal growth factor and spermatogenesis. Archives of Andrology 40 133-146. (https://doi. org/10.3109/01485019808987936)

Zhang Q, Fong CC, Yu WK, Chen Y, Wei F, Koon CM, Lau KM, Leung PC, Lau CB, Fung KP et al. 2012 Herbal formula Astragali Radix and Rehmanniae Radix exerted wound healing effect on human skin fibroblast cell line Hs27 via the activation of transformation growth factor (TGF-beta) pathway and promoting extracellular matrix (ECM) deposition. Phytomedicine 20 9-16. (https://doi.org/10.1016/j. phymed.2012.09.006)

Received 7 June 2017

First decision 29 June 2017

Revised manuscript received 17 October 2017

Accepted 13 November 2017 